\title{
Photochemistry of the Venus Atmosphere
}

\author{
Michael B. Mcelroy, Nien Dak Sze and Yuk Ling Yung \\ Center for Earth and Planetary Physics, Harvard University, Cambridge, Mass. 02138
}

(Manuscript received 14 May 1973, in revised form 27 June 1973)

\begin{abstract}
Carbon monoxide, produced in the Venus atmosphere by photolysis of $\mathrm{CO}_{2}$, is removed mainly by reaction with $\mathrm{OH}$. The radical $\mathrm{OH}$ is formed in part by photolysis of $\mathrm{H}_{2} \mathrm{O}_{2}$, in part by reaction of $\mathrm{O}$ with $\mathrm{HO}_{2}$. Photolysis of $\mathrm{HCl}$ provides a major source of $\mathrm{H}$ radicals near the visible clouds of Venus and plays a major role in the overall photochemistry. The mixing ratio of $\mathrm{O}_{2}$ is estimated to be approximately $10^{-7}$, about a factor of 10 less than a recent observational upper limit reported by Traub and Carleton. A detailed model, which accounts for the photochemical stability of Venus $\mathrm{CO}_{2}$, is presented and discussed.
\end{abstract}

\section{Introduction}

The atmosphere of Venus is composed primarily of $\mathrm{CO}_{2}$, but contains detectable trace quantities of $\mathrm{CO}$, $\mathrm{H}_{2} \mathrm{O}, \mathrm{HCl}$ and $\mathrm{HF}$. Carbon dioxide is dissociated readily by sunlight at wavelengths $<2000 \AA$, and the observed abundance of $\mathrm{CO}$, approximately $5 \times 10^{-5}$ that of $\mathrm{CO}_{2}$, could be produced photochemically in as little as 200 years. Similar remarks apply to $\mathrm{O}_{2}$. Spectroscopic observations by Traub and Carleton (1973) suggest an upper limit to the $\mathrm{O}_{2}$ mixing ratio of about $10^{-6}$, and an abundance in excess of this limit could be formed photochemically in less than 10 years. Our present task is to account for the stability of $\mathrm{CO}_{2}$ in the atmosphere of Venus and, in so doing, to provide an explanation for the remarkable deficiency of $\mathrm{CO}$ and $\mathrm{O}_{2}$.

A similar problem has arisen for Mars and was treated recently by McElroy and Donahue (1972) and by Parkinson and Hunten (1972). It appears that recombination of $\mathrm{CO}_{2}$ in the Martian atmosphere is catalyzed by trace quantities of $\mathrm{H}$ and $\mathrm{OH}$, produced by photolysis of $\mathrm{H}_{2} \mathrm{O}$. Removal of $\mathrm{CO}$ proceeds by two main paths:

$$
\left.\begin{array}{rl}
\mathrm{I}+\mathrm{O}_{2}+\mathrm{CO}_{2} & \rightarrow \mathrm{HO}_{2}+\mathrm{CO}_{2} \\
\mathrm{O}+\mathrm{HO}_{2} & \rightarrow \mathrm{OH}+\mathrm{O}_{2} \\
\mathrm{CO}+\mathrm{OH} & \rightarrow \mathrm{CO}_{2}+\mathrm{H}
\end{array}\right\},
$$

and

$$
\left.\begin{array}{rl}
2\left[\mathrm{H}+\mathrm{O}_{2}+\mathrm{CO}_{2}\right. & \left.\rightarrow \mathrm{HO}_{2}+\mathrm{CO}_{2}\right] \\
2 \mathrm{HO}_{2} & \rightarrow \mathrm{H}_{2} \mathrm{O}_{2}+\mathrm{O}_{2} \\
h \nu+\mathrm{H}_{2} \mathrm{O}_{2} & \rightarrow 2 \mathrm{OH} \\
2[\mathrm{CO}+\mathrm{OH} & \left.\rightarrow \mathrm{CO}_{2}+\mathrm{H}\right]
\end{array}\right\}
$$

The first corresponds to the net reaction

$$
\mathrm{H}+\mathrm{CO}+\mathrm{O} \rightarrow \mathrm{H}+\mathrm{CO}_{2},
$$

and the second is equivalent to

$$
2 \mathrm{H}+2 \mathrm{CO}+\mathrm{O}_{2} \rightarrow 2 \mathrm{H}+2 \mathrm{CO}_{2} .
$$

We shall argue here that recombination of $\mathrm{CO}_{2}$ in the atmosphere of Venus proceeds by a combination of (1) and (2). The necessary source of $\mathrm{H}$ is provided by

$$
h \nu+\mathrm{HCl} \rightarrow \mathrm{H}+\mathrm{Cl},
$$

followed by

$$
\mathrm{Cl}+\mathrm{H}_{2} \rightarrow \mathrm{HCl}+\mathrm{H} \text {. }
$$

Reactions (3) and (4) lead to net dissociation of $\mathrm{H}_{2}$, the rate of which can be estimated if the concentration of $\mathrm{HCl}$ is taken as given.

\section{Assumptions and general approach}

Using the observed mixing ratio of $\mathrm{HCl}$, about $6 \times 10^{-7}$ according to Connes et al. (1967), we estimate a global mean rate for production of $\mathrm{H}$ atoms by (3) and (4) equal to $4 \times 10^{11} \mathrm{~cm}^{-2} \mathrm{sec}^{-1}$. The corresponding rate for destruction of $\mathrm{H}_{2}$ is $2 \times 10^{11} \mathrm{~cm}^{-2} \mathrm{sec}^{-1}$ and must be balanced by a source of comparable magnitude. As we shall see, the necessary $\mathrm{H}_{2}$ source is provided in part by

$$
\mathrm{H}+\mathrm{HO}_{2} \rightarrow \mathrm{H}_{2}+\mathrm{O}_{2},
$$

with an additional contribution from the global reaction

$$
\mathrm{CO}+\mathrm{H}_{2} \mathrm{O} \rightarrow \mathrm{CO}_{2}+\mathrm{H}_{2} \text {. }
$$

Reaction (5) occurs primarily above the visible cloud tops, where the atmospheric pressure is about $0.2 \mathrm{~atm}$ and the temperature about $250 \mathrm{~K}$. Reaction (6) occurs mainly in the deep atmosphere, near the surface, where the pressure is about $95 \mathrm{~atm}$ and the temperature about $750 \mathrm{~K}$.

We shall assume that $\mathrm{CO}$ in the atmosphere of Venus is produced primarily by photolysis of $\mathrm{CO}_{2}$. We assume further that $\mathrm{CO}$ is mixed uniformly throughout the atmosphere. The total abundance of $\mathrm{CO}$ is then about $10^{23}$ molecules $\mathrm{cm}^{-2}$ and there must be a comparable 
amount of free oxygen. Our model should account for this oxygen reservoir. The observations of Traub and Carleton (1973) seem to rule out $\mathrm{O}_{2}$ as the major component of the reservoir. A more likely candidate is water, formed by the reaction sequence

$$
\left.\begin{array}{rl}
h \nu+\mathrm{HCl} & \rightarrow \mathrm{H}+\mathrm{Cl} \\
\mathrm{Cl}+\mathrm{H}_{2} & \rightarrow \mathrm{HCl}+\mathrm{H} \\
2\left[\mathrm{H}+\mathrm{O}_{2}+\mathrm{CO}_{2}\right. & \left.\rightarrow \mathrm{HO}_{2}+\mathrm{CO}_{2}\right] \\
2 \mathrm{HO}_{2} & \rightarrow \mathrm{H}_{2} \mathrm{O}_{2}+\mathrm{O}_{2} \\
h \nu+\mathrm{H}_{2} \mathrm{O}_{2} & \rightarrow 2 \mathrm{OH} \\
\mathrm{CO}+\mathrm{OH} & \rightarrow \mathrm{CO}_{2}+\mathrm{H} \\
\mathrm{H}+\mathrm{O}_{2}+\mathrm{CO}_{2} & \rightarrow \mathrm{HO}_{2}+\mathrm{CO}_{2} \\
\mathrm{OH}+\mathrm{HO}_{2} & \rightarrow \mathrm{H}_{2} \mathrm{O}+\mathrm{O}_{2}
\end{array}\right\}
$$

for which the equivalent stoichiometric equation is

$$
\mathrm{H}_{2}+\mathrm{O}_{2}+\mathrm{CO} \rightarrow \mathrm{H}_{2} \mathrm{O}+\mathrm{CO}_{3} \text {. }
$$

Our detailed models assume, therefore, that the total abundance of $\mathrm{H}_{2} \mathrm{O}$ must be at least as large as that of $\mathrm{CO}$, i.e., that the mixing ratio of $\mathrm{H}_{2} \mathrm{O}$ in the lower atmosphere must be $5 \times 10^{-5}$ or larger. This assumption is consistent with, but not required by, the available observational data. Reported mixing ratios for $\mathrm{H}_{2} \mathrm{O}$ range from low values of order $10^{-6}$ (Young, 1972; Fink et al., 1972) to high values of order $10^{-2}$ (Avduevsky et al., 1970; Vinogradov et al., 1971). The low values are associated with infrared spectroscopic studies which emphasize conditions near or above the visible cloud deck. The highest mixing ratios were detected by Venera probes and refer to conditions near the 1-atm pressure level. It is clear, however, from recent studies of the Venus emission spectrum at radio wavelengths (Janssen et al., 1973) that the Venera measurements cannot represent planetary mean conditions. The average mixing ratio of $\mathrm{H}_{2} \mathrm{O}$ must be less than $2 \times 10^{-3}$ at pressure levels of about $2 \mathrm{~atm}$ (Janssen et al., 1973). Radio (Berge and Greisen, 1969; Sinclair et al., 1972) and radar (Rogers et al., 1972) data would permit, but do not require, larger mixing ratios, $\sim 5 \times 10^{-3}$, at lower atmospheric levels.

In view of the present uncertainties regarding the abundance and height distribution of Venus $\mathrm{H}_{2} \mathrm{O}$, we propose here to consider two distinct models, one dry, one wet. The dry model assumes that the mixing ratio of $\mathrm{H}_{2} \mathrm{O}$ in the stratosphere may be significantly less than that in the lower atmosphere. This result could hold if $\mathrm{H}_{2} \mathrm{O}$ were a major component of the Venus clouds. It would be appropriate, in particular, if the main clouds were composed of $\mathrm{H}_{2} \mathrm{SO}_{4}$ as suggested recently by Young (1973). The wet model assumes that the stratospheric mixing ratio is the same as the mixing ratio in the lower atmosphere. The wet model, as implied earlier, is constrained to give a $\mathrm{H}_{2} \mathrm{O}$ mixing ratio greater than or equal to that of $\mathrm{CO}$ at all heights.

Water formed by reactions (7) must be removed elsewhere at an equivalent rate. In the models discussed here, removal of $\mathrm{H}_{2} \mathrm{O}$ occurs in the upper atmosphere by photolysis followed by

$$
\left.\begin{array}{rl}
\mathrm{CO}+\mathrm{OH} & \rightarrow \mathrm{CO}_{2}+\mathrm{H} \\
\mathrm{H}+\mathrm{O}_{2}+\mathrm{CO}_{2} & \rightarrow \mathrm{HO}_{2}+\mathrm{CO}_{2} \\
\mathrm{H}+\mathrm{HO}_{2} & \rightarrow \mathrm{H}_{2}+\mathrm{O}_{2}
\end{array}\right\}
$$

with additional loss in the lower atmosphere associated with reaction (6).

The strategy adopted for this work is as follows. We assume that $\mathrm{CO}, \mathrm{O}_{2}, \mathrm{HCl}, \mathrm{H}_{2}$ and $\mathrm{H}_{2} \mathrm{O}$ are mixed homogeneously with $\mathrm{CO}_{2}$, at least above the visible cloud deck. We assume further that the abundances of odd hydrogen, odd oxygen and free chlorine are given by photochemical equilibrium. For present purposes $\mathrm{H}, \mathrm{OH}, \mathrm{HO}_{2}$ and $\mathrm{H}_{2} \mathrm{O}_{2}$ are considered as odd hydrogen; $\mathrm{O}, \mathrm{OH}$ and $\mathrm{O}_{3}$ as odd oxygen; and $\mathrm{Cl}$ and $\mathrm{Cl}_{2}$ as free chlorine.

The assumption of photochemical equilibrium for odd $\mathrm{H}$ is equivalent (see Appendix A) to the staternent

$$
p\left(\mathrm{H}_{2}\right)+p\left(\mathrm{H}_{2} \mathrm{O}\right)=0,
$$

where $p(i)$ denotes the net rate for production of species $i$ at height z. Similarly, photochemical equilibrium for odd $\mathrm{O}$ and free chlorine requires

$$
\begin{aligned}
p\left(\mathrm{CO}_{2}\right)+p\left(\mathrm{H}_{2} \mathrm{O}\right)+2 p\left(\mathrm{O}_{2}\right) & =0, \\
p(\mathrm{HCl}) & =0 .
\end{aligned}
$$

Acceptable physical solutions must satisfy the additional constraints

$$
\int_{0}^{\infty} p(i) d Z=0
$$

where $i$ denotes $\mathrm{CO}_{2}, \mathrm{O}_{2}, \mathrm{H}_{2} \mathrm{O}, \mathrm{H}_{2}$ and $\mathrm{HCl}$. If we assume (9)-(11) as given, then (12) introduces an additional pair of independent constraints. If (12) is satisfied for any pair of linearly independent constituents, for example $\mathrm{O}_{2}$ and $\mathrm{H}_{2}$ or $\mathrm{O}_{2}$ and $\mathrm{CO}$, then Eqs. (9)-(11) ensure that (12) must be satisfied for all $i$.

In practice, we take the mixing ratios of $\mathrm{HCl}$ and $\mathrm{H}_{2} \mathrm{O}$ as given. We then vary the mixing ratios of $\mathrm{O}_{2}$ and $\mathrm{CO}$ in an attempt to satisfy the integral constraints (12) for all major species. There is, of course, no guarantee that any physically acceptable solution should exist to the problem as posed. Indeed, we find it necessary in the dry model to allow for removal of $\mathrm{H}_{2} \mathrm{O}$ in the lower atmosphere by reaction (6). The magnitude of the downward flux of $\mathrm{H}_{2} \mathrm{O}$ is a function of the value assumed for the rate constant for

$$
\mathrm{OH}+\mathrm{HO}_{2} \rightarrow \mathrm{H}_{2} \mathrm{O}+\mathrm{O}_{2} \text {. }
$$

Somewhat arbitrarily, we adopted a value $10^{-10} \mathrm{~cm}^{3}$ $\mathrm{sec}^{-1}$ for this constant in the dry model, a factor of 2 less than that used in the wet model. It is possible in the wet model to find an acceptable solution in which height-integrated production and loss rates are in balance for all major constituents without the need to invoke lower atmospheric chemistry. Both wet and dry 
Table 1. Height $z$, above the visible cloud tops, taken at a planetocentric distance of $6112 \mathrm{~km}$, number density $n_{\text {, and tem- }}$ perature $T$ for the model atmosphere.

\begin{tabular}{ccc}
$\begin{array}{c}\text { Height } \\
(\mathrm{km})\end{array}$ & $\begin{array}{c}\text { Number density } \\
\left(\mathrm{cm}^{-3}\right)\end{array}$ & $\begin{array}{c}\text { Temperature } \\
\left({ }^{\circ} \mathrm{K}\right)\end{array}$ \\
\hline 0 & $6.8(18)$ & 255 \\
2 & $4.2(18)$ & 246 \\
6 & $2.1(18)$ & 232 \\
10 & $1.0(18)$ & 217 \\
14 & $4.5(17)$ & 200 \\
18 & $2.0(17)$ & 188 \\
22 & $7.4(16)$ & 180 \\
26 & $2.8(16)$ & 175 \\
30 & $9.9(15)$ & 171 \\
39 & $1.0(15)$ & 165 \\
44 & $2.4(14)$ & 183 \\
54 & $1.6(13)$ & 212 \\
64 & $1.5(12)$ & 246 \\
74 & $1.8(11)$ & 334 \\
\hline
\end{tabular}

models provide satisfactory solutions to the overall stability problem.

The present work does not explicitly allow for atmospheric dynamics. We assumed implicitly that dynamics plays a dominent role for $\mathrm{CO}_{2}, \mathrm{CO}, \mathrm{O}_{2}, \mathrm{H}_{2} \mathrm{O}, \mathrm{H}_{2}$ and $\mathrm{HCl}$, but that chemistry dominates for odd $\mathrm{H}$, odd $\mathrm{O}$ and free $\mathrm{Cl}$. In order to assess the validity of these assumptions we compute chemical time constants for major photochemically active species. It seems probable that $\mathrm{CO}, \mathrm{O}_{2}, \mathrm{H}_{2} \mathrm{O}, \mathrm{H}_{2}$ and $\mathrm{HCl}$ are indeed uniformly mixed with $\mathrm{CO}_{2}$ over the major height range of interest here. On the other hand, the assumption of photochemical equilibrium may be suspect for $\mathrm{H}, \mathrm{O}$ and $\mathrm{Cl}$, particularly at higher altitudes. The neglect of dynamics is unlikely, however, to introduce any major error in the present discussion. We offer a qualitative discussion of the possible effects of dynamics.

\section{Chemical model}

The model atmosphere adopted for present purposes is summarized in Table 1. The height scale is referred to a zero reference level near the top of the visible cloud deck, at a planetocentric distance of $6112 \mathrm{~km}$. A more detailed description of the model, which was constructed on the basis of the available spacecraft data, is given elsewhere (NASA, 1972).

Solar fluxes in the visual and near-ultraviolet were taken from the Handbook of Geophysics and Space Environments (1965). We used data by Detwiler et al. (1961), as tabulated by Brinkmann et al. (1966), for the wavelength interval $1750-3000 \AA$. Below $1750 \AA$ we used more recent observations by Widing et al. (1970). Absorption cross sections for $\mathrm{CO}_{2}, \mathrm{HCl}$ and $\mathrm{H}_{2} \mathrm{O}$ were taken from Shemansky (1972), Romand and Vodar (1948) and Thompson et al. (1963), respectively.

The detailed chemical model is summarized in Table 2 and the relevant photochemical equations are presented and discussed in Appendix A. For both wet and dry models, loss of odd hydrogen proceeds pri- marily by (5). Below $6 \mathrm{~km}$, the relative concentrations of $\mathrm{H}, \mathrm{OH}$ and $\mathrm{HO}_{2}$ are controlled by $k_{3}, k_{5}, k_{9}$ and $J_{6}$. Then

$$
\begin{aligned}
& {\left[\mathrm{HO}_{2}\right]=\left\{\frac{k_{3}\left[\mathrm{O}_{2}\right]\left[\mathrm{CO}_{2}\right]\left(J_{5}\left[\mathrm{H}_{2} \mathrm{O}\right]+J_{4}[\mathrm{HCl}]\right)}{2 k_{9} k_{10}}\right\}^{\frac{3}{3}},} \\
& {[\mathrm{H}]=\frac{2^{\frac{1}{3}} k_{9}^{\frac{1}{3}}}{\left[\mathrm{O}_{2}\right]^{\frac{3}{3}}\left[\mathrm{CO}_{2}\right]^{\frac{1}{3}} k_{3^{\frac{1}{3}} k_{10}}}\left\{J_{5}\left[\mathrm{H}_{2} \mathrm{O}\right]+J_{4}[\mathrm{HCl}]\right\}^{\frac{\pi}{3}} \text {, }}
\end{aligned}
$$

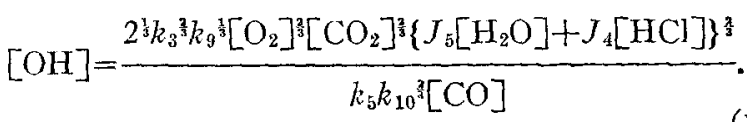

Between $6 \mathrm{~km}$ and $18 \mathrm{~km}$, reactions $k_{4}$ and $k_{12}$ are more important than $k_{9}$ and $J_{6}$. In this case

$$
\left[\mathrm{HO}_{2}\right]=\frac{k_{3}\left[\mathrm{O}_{2}\right]\left[\mathrm{CO}_{2}\right]\left\{J_{4}[\mathrm{HCl}]+J_{5}\left[\mathrm{H}_{2} \mathrm{O}\right]\right\}}{k_{10} J_{1}\left[\mathrm{CO}_{2}\right]},
$$

TABLE 2. Reactions and rate constants for Venus. Rate constants for 2- and 3-body reactions have units $\mathrm{cm}^{3} \mathrm{sec}^{-1}$ and $\mathrm{cm}^{6} \mathrm{sec}^{-1}$, respectively. Planetary mean rates for photolysis have

\begin{tabular}{|c|c|c|c|}
\hline \multicolumn{2}{|c|}{ Reaction } & Rate & Reference \\
\hline $\begin{array}{l}h \nu+\mathrm{CO}_{2} \\
h \nu+\mathrm{O}_{2} \\
h \nu+\mathrm{O}_{3} \\
h \nu+\mathrm{HCl} \\
h \nu+\mathrm{H}_{2} \mathrm{O} \\
h \nu+\mathrm{H}_{2} \mathrm{O}_{2} \\
h \nu+\mathrm{Cl}_{2} \\
\mathrm{CO}+\mathrm{O}+\mathrm{CO}_{2}\end{array}$ & $\begin{array}{l}\rightarrow \mathrm{CO}+\mathrm{O} \\
\rightarrow \mathrm{O}+\mathrm{O} \\
\rightarrow \mathrm{O}+\mathrm{O}_{2} \\
\rightarrow \mathrm{H}+\mathrm{Cl} \\
\rightarrow \mathrm{OH}+\mathrm{H} \\
\rightarrow \mathrm{OH}+\mathrm{OH} \\
\rightarrow \mathrm{Cl}+\mathrm{Cl} \\
\rightarrow \mathrm{CO}_{2}+\mathrm{CO}_{2}\end{array}$ & $\begin{array}{l}J_{1}=1 \times 10^{-11} \\
J_{2}=1 \times 10^{-9} \\
J_{8}=8.8 \times 10^{-3} \\
J_{4}=1 \times 10^{-7} \\
J_{6}=4 \times 10^{-7} \\
J_{6}=1 \times 10^{-4} \\
J_{7}=1.3 \times 10^{-3} \\
k_{1}=2 \times 10^{-37}\end{array}$ & $\begin{array}{c}\text { (see text) } \\
\text { (see text) } \\
\text { (see text) } \\
\text { (see text) } \\
\text { (see text) } \\
\text { (see text) } \\
\text { (see text) } \\
\text { (a) }\end{array}$ \\
\hline $\mathrm{O}+\mathrm{O}+\mathrm{CO}_{2}$ & $\rightarrow \mathrm{O}_{2}+\mathrm{CO}_{2}$ & $k_{2}=3 \times 10^{-83}\left(\frac{T}{300}\right)^{-6}$ & (b) \\
\hline $\mathrm{H}+\mathrm{O}_{2}+\mathrm{CO}_{2}$ & $\rightarrow \mathrm{HO}_{2}+\mathrm{CO}_{2}$ & $k_{3}=2 \times 10^{-31}\left(\frac{T}{273}\right)^{-1.2}$ & (c) \\
\hline $\mathrm{O}+\mathrm{HHO}_{2}$ & $\rightarrow \mathrm{OH}+\mathrm{O}_{2}$ & $k_{4}=7 \times 10^{-11}$ & (d) \\
\hline $\mathrm{CO}+\mathrm{OH}$ & $\rightarrow \mathrm{CO}_{2}+\mathrm{H}$ & $k_{5}=9 \times 10^{-19} \exp \left(-\frac{500}{T}\right)$ & (e) \\
\hline $\mathrm{H}+\mathrm{O}_{3}$ & $\rightarrow \mathrm{OH}+\mathrm{O}_{2}$ & $k_{6}=2.6 \times 10^{-11}$ & (f) \\
\hline $\mathrm{O}+\mathrm{O}_{2}+\mathrm{CO}_{2}$ & $\rightarrow \mathrm{O}_{3}+\mathrm{CO}_{2}$ & $k_{7}=1.4 \times 10^{-33}\left(\frac{T}{300}\right)^{-2}$ & (g) \\
\hline $\begin{array}{l}\mathrm{O}+\mathrm{OH} \\
\mathrm{HO}_{2}+\mathrm{HO}_{2} \\
\mathrm{H}+\mathrm{HO}_{2} \\
\mathrm{OH}+\mathrm{HO}_{2} \\
\mathrm{H}+\mathrm{HO}_{2} \\
\mathrm{H}+\mathrm{H}+\mathrm{CO}_{2}\end{array}$ & $\begin{array}{l}\rightarrow \mathrm{O}_{2}+\mathrm{H} \\
\rightarrow \mathrm{H}_{2} \mathrm{O}_{2}+\mathrm{O}_{2} \\
\rightarrow \mathrm{H}_{2}+\mathrm{O}_{2} \\
\rightarrow \mathrm{H}_{2} \mathrm{O}+\mathrm{O}_{2} \\
\rightarrow \mathrm{OH}+\mathrm{OH} \\
\rightarrow \mathrm{H}_{2}+\mathrm{CO}_{2}\end{array}$ & $\begin{aligned} k_{8} & =5 \times 10^{-11} \\
k_{9} & =9.5 \times 10^{-12} \\
k_{10} & =1 \times 10^{-12} \\
k_{11} & =2 \times 10^{-10} \\
k_{12} & =3 \times 10^{-11} \\
k_{13} & =2.6 \times 10^{-32}\end{aligned}$ & $\begin{array}{l}(f) \\
(d) \\
(e) \\
(f) \\
(h) \\
(i)\end{array}$ \\
\hline $\mathrm{Cl}+\mathrm{H}_{2}$ & $\rightarrow \mathrm{HCl}+\mathrm{H}$ & $k_{14}=8 \times 10^{-11} \exp \left(-\frac{2480}{T}\right)$ & $(k, m)$ \\
\hline $\mathrm{Cl}+\mathrm{Cl}+\mathrm{CO}_{2}$ & $\rightarrow \mathrm{Cl}_{2}+\mathrm{CO}_{2}$ & $k_{15}=2.7 \times 10^{-32}$ & (j) \\
\hline
\end{tabular}
units $\sec ^{-1}$, and numerical values are presented for an approximate elevation of $30 \mathrm{~km}$ above the visible cloud deck.

\footnotetext{
(a) Simonaites and Heicklen (1972).

(b) Reeves et al. (1960)

(c) Baulch el al. (1969).

(d) Hochanadel et al. (1969).

(e) McElroy and Donahue (1972).

(f) Kaufman (1964).

(g) Kaufman (1969).

(h) K.Schofield (1967).

(i) Larkin and Thrush (1964).

(j) Bader and Ogryzlo (1964).

(k) Westenberg and de Hass (1968).

(l) Dainton and Ayscough (1967).
} 


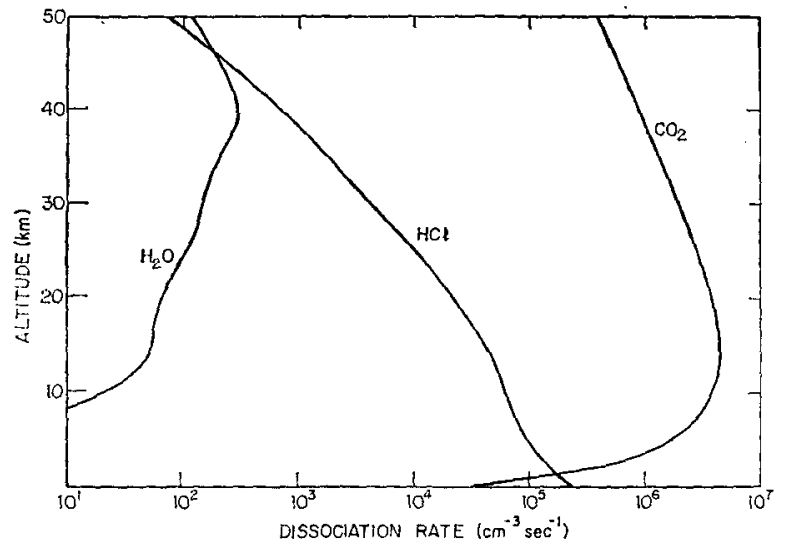

Fig. 1. Dissociation rates for $\mathrm{H}_{2} \mathrm{O}, \mathrm{HCl}$ and $\mathrm{CO}_{2}$ as a function of height above the Venus cloud deck.

$$
\begin{aligned}
{[\mathrm{H}] } & =\frac{J_{1}\left[\mathrm{CO}_{2}\right]}{k_{3}\left[\mathrm{O}_{2}\right]\left[\mathrm{CO}_{2}\right]}, \\
{[\mathrm{OH}] } & =\frac{J_{1}\left[\mathrm{CO}_{2}\right]}{k_{5}[\mathrm{CO}]}, \\
{[\mathrm{O}] } & =\frac{k_{10}\left\{J_{1}\left[\mathrm{CO}_{2}\right]\right\}^{2}}{k_{4} k_{3}\left[\mathrm{O}_{2}\right]\left[\mathrm{CO}_{2}\right]\left\{J_{4}[\mathrm{HCl}]+J_{5}\left[\mathrm{H}_{2} \mathrm{O}\right]\right\}} .
\end{aligned}
$$

Above $20 \mathrm{~km}, \mathrm{OH}$ and $\mathrm{HO}_{2}$ are controlled by $k_{8}$ and $k_{4}$, and

$$
\begin{aligned}
{[\mathrm{H}] } & =\left\{\frac{J_{4}[\mathrm{HCl}]+J_{5}\left[\mathrm{H}_{2} \mathrm{O}\right]}{k_{13}\left[\mathrm{CO}_{2}\right]}\right\}^{\frac{1}{3}}, \\
{\left[\mathrm{HO}_{2}\right] } & =\frac{k_{3}\left[\mathrm{O}_{2}\right]\left[\mathrm{CO}_{2}\right]}{k_{4}}\left\{\frac{2 k_{2}\left(J_{4}[\mathrm{HCl}]+J_{5}\left[\mathrm{H}_{2} \mathrm{O}\right]\right)}{k_{13} J_{1}\left[\mathrm{CO}_{2}\right]}\right\}^{\frac{3}{3}}, \\
{[\mathrm{OH}] } & =\frac{k_{3}\left[\mathrm{O}_{2}\right]\left[\mathrm{CO}_{2}\right]}{k_{8}}\left\{\frac{2 k_{2}\left(J_{4}[\mathrm{HCl}]+J_{5}\left[\mathrm{H}_{2} \mathrm{O}\right]\right)}{k_{13} J_{1}\left[\mathrm{CO}_{2}\right]}\right\}^{\frac{3}{2}}, \\
{[\mathrm{O}] } & =\left(\frac{J_{1}}{2 k_{2}}\right)^{\frac{1}{2}}
\end{aligned}
$$

Relations (14)-(24) hold approximately for the height ranges as indicated and provide a valuable analytic framework for interpretation of the detailed numerical results. We note in particular that the analytic results given here imply that the rate $R$ for recombination of $\mathrm{CO}$ can be approximated by

$$
\begin{aligned}
& R(\mathrm{CO})=2^{\frac{1}{3}} k_{3}{ }^{\frac{2}{3}} k_{9}{ }^{\frac{1}{3}} k_{10}{ }^{-\frac{3}{3}}\left[\mathrm{O}_{2}\right]^{?}\left[\mathrm{CO}_{2}\right]^{3} \\
& \times\left\{J_{5}\left[\mathrm{H}_{2} \mathrm{O}\right]+J_{4}[\mathrm{HCl}]\right\}^{\frac{2}{3}}, \\
& R(\mathrm{CO})=J_{1}\left[\mathrm{CO}_{2}\right], \\
& R(\mathrm{CO})=\frac{k_{5} k_{3}[\mathrm{CO}]\left[\mathrm{O}_{2}\right]\left[\mathrm{CO}_{2}\right]}{k_{8}} \\
& \times\left\{\frac{2 k_{2}\left(J_{4}[\mathrm{HCl}]+J_{5}\left[\mathrm{H}_{2} \mathrm{O}\right]\right)}{k_{13} J_{1}\left[\mathrm{CO}_{2}\right]}\right\}^{\frac{1}{2}},
\end{aligned}
$$

for the height ranges $0-6 \mathrm{~km}, 6-18 \mathrm{~km}$, and above $20 \mathrm{~km}$ respectively. Recombination of $\mathrm{CO}$ takes place primarily below $20 \mathrm{~km}$. Both (1) and (2) are important and the height-integrated rate for recombination of $\mathrm{CO}$ varies approximately as $f_{\mathrm{O}_{2}}^{0.6}$ where $f_{\mathrm{O}_{2}}$ is the mixing ratio of $\mathrm{O}_{2}$. It is interesting to note that the heightintegrated rate for recombination of $\mathrm{CO}$ is essentially independent of $f_{\mathrm{O}_{2}}$ if loss of odd hydrogen proceeds mainly by (13) (see Appendix A), in which case $\mathrm{H}_{2}$ cannot be conserved.

The relative rates for production of $\mathrm{H}_{2} \mathrm{O}$ and $\mathrm{H}_{2}$ depend on the abundances of $\mathrm{OH}$ and $\mathrm{H}$. Most of the $\mathrm{H}_{2} \mathrm{O}$ is formed below $5 \mathrm{~km}$ where the formation rate is given by

$$
R\left(\mathrm{H}_{2} \mathrm{O}\right)=\frac{k_{3} k_{11}\left[\mathrm{O}_{2}\right]\left[\mathrm{CO}_{2}\right]\left\{J_{5}\left[\mathrm{H}_{2} \mathrm{O}\right]+J_{4}[\mathrm{HCl}]\right\}}{k_{5} k_{10}[\mathrm{CO}]} .
$$

The height-integrated rate for production of $\mathrm{H}_{2} \mathrm{O}$ is thus directly proportional to $k_{11} f_{\mathrm{O}_{2}}$ and inversely proportional to $k_{10} f_{\mathrm{CO}}$.

Dissociation of $\mathrm{CO}_{2}$ above $20 \mathrm{~km}$ is followed by production of $\mathrm{O}_{2}$, which is transported to lower altitudes and removed mainly by (2). Approximately half the oxygen formed by photolysis of $\mathrm{CO}_{2}$ recombines by (1), the remainder by (2).

\section{Results}

Figure 1 shows planetary mean rates for photodissociation of $\mathrm{CO}_{2}, \mathrm{HCl}$ and $\mathrm{H}_{2} \mathrm{O}$. These results were obtained with the dry atmospheric model in which the mixing ratios of $\mathrm{HCl}$ and $\mathrm{H}_{2} \mathrm{O}$ are $7.5 \times 10^{-7}$ and $1.0 \times 10^{-6}$, respectively. The atmospheric capacity is due primarily to $\mathrm{CO}_{2}$, and results for $\mathrm{H}_{2} \mathrm{O}$ and $\mathrm{HCl}$ can be readily scaled to allow for different mixing ratios of these species. In particular, dissociation rates for $\mathrm{H}_{2} \mathrm{O}$ in the wet model, for which the $\mathrm{H}_{2} \mathrm{O}$ mixing ratio is $5 \times 10^{-5}$, are simply obtained by multiplying the relevant data in Fig. 1 by a factor of 50 . Effects of cloud opacity were not explicitly considered in the present calculations but are not expected to seriously modify the conclusions.

The results shown here differ in at least one important respect from calculations presented earlier by Prinn (1971). We note that dissociation of $\mathrm{CO}_{2}$ is significant at all altitudes in Fig. 1. In contrast, Prinn's analysis assumed that dissociation of $\mathrm{CO}_{2}$ should be negligible below $20 \mathrm{~km}$. The discrepancy is attributed to differences in the choice of absorption cross section for $\mathrm{CO}_{2}$. Prinn (1971) used data summarized by Schultz and Holland (1963) and treated only absorption at wavelengths $<1975 \AA$. The present analysis uses Shemansky's more recent cross sections (1972). We assumed that the quantum yield from $\mathrm{CO}_{2}$ photolysis was unity at wavelengths $>1670 \AA$, as suggested by Inn and Heimerl (1971). Dissociation in the height range $0-20 \mathrm{~km}$ is primarily due to absorption of radiation in the wavelength band $1975-2075 \AA$. 
The height-integrated rate for photolysis of $\mathrm{H}_{2} \mathrm{O}$ in the dry model is small compared with the heightintegrated rate for photolysis of $\mathrm{HCl}$. It is consequently difficult to find a balance for $\mathrm{H}_{2} \mathrm{O}$ in the dry model. We must choose the parameters in such a way as to minimize production of $\mathrm{H}_{2} \mathrm{O}$ at low altitudes. In our judgment, the most uncertain parameters are $f_{\mathrm{O}_{2}}, k_{10}$ and $k_{11}$, arranged in order of increasing uncertainty. But, the ratio $f_{\mathrm{O}_{2}} / k_{10}$ is fixed by the need to find a balance for $\mathrm{CO}$ [see Eq. (25)]. Production of $\mathrm{H}_{2} \mathrm{O}$, as given by (28), varies as $k_{11} f_{O_{2}} / k_{10}$. It follows that only $k_{11}$ is at our disposal in order to optimize the photochemical solution. We chose $k_{11}=10^{-10} \mathrm{~cm}^{3} \mathrm{sec}^{-1}$ for the dry model, a factor of 2 less than the room temperature measurement reported by Hochanadel et al. (1972). The discrepancy could reflect an inaccuracy in the laboratory determination of the density of $\mathrm{HO}_{2}$ and in order to cover this possibility we also adjusted the value of $k_{g}$. The value listed in Table 2 was taken from Hochanadel $e t a l$. In the dry model we took $k_{9}=3 \times 10^{-12}$ $\mathrm{cm}^{3} \mathrm{sec}^{-1}$. Other parameters of the dry model are as listed in Table 2.

Densities for $\mathrm{H}, \mathrm{O}, \mathrm{OH}, \mathrm{HO}_{2}$ and $\mathrm{H}_{2} \mathrm{O}_{2}$ computed with the dry model are illustrated in Fig. 2. Densities of $\mathrm{CO}_{2}$ are also included for comparison. The mixing ratio of $\mathrm{O}_{2}$ is $9.4 \times 10^{-8}$, and the corresponding value for $\mathrm{CO}$ is $8.8 \times 10^{-5}$. The abundances of $\mathrm{O}_{2}$ and $\mathrm{H}_{2} \mathrm{O}_{2}$ are comparable at lower altitudes. The number density of $\mathrm{H}_{2} \mathrm{O}_{2}$ is $7.4 \times 10^{10} \mathrm{~cm}^{-3}$ at $z=0$, which should be compared with number densities of $6.8 \times 10^{12}, 5.1 \times 10^{12}$ and $6.4 \times 10^{11} \mathrm{~cm}^{-3}$ for $\mathrm{H}_{2} \mathrm{O}, \mathrm{HCl}$ and $\mathrm{O}_{2}$, respectively.

Rates for some key reactions in the dry model are illustrated in Fig. 3. Molecular oxygen is formed mainly above $18 \mathrm{~km}$, with the major contribution coming from $k_{2}$. Dissociation of $\mathrm{CO}_{2}$ below $18 \mathrm{~km}$ is balanced by recombination via the reaction sequence (1). The height-integrated rate for production of $\mathrm{O}_{2}$ is $3 \times 10^{12}$ $\mathrm{cm}^{-2} \mathrm{sec}^{-1}$, this production being balanced by removal through the reaction sequence (2). The heightintegrated rate for production of $\mathrm{H}_{2}$ is $2.2 \times 10^{11} \mathrm{~cm}^{-2}$ $\mathrm{sec}^{-2}$ which should be compared with a computed loss rate of $2.3 \times 10^{11} \mathrm{~cm}^{-2} \mathrm{sec}^{-1}$. Production of $\mathrm{H}_{2} \mathrm{O}$ exceeds removal of $\mathrm{H}_{2} \mathrm{O}$ by $1.3 \times 10^{10} \mathrm{~cm}^{-2} \mathrm{sec}^{-1}$, and there is a similar small imbalance for $\mathrm{CO}$.

Continuity of species requires upward fluxes of $\mathrm{CO}_{2}$ and $\mathrm{H}_{2}$ and corresponding downward fluxes of $\mathrm{CO}$ and $\mathrm{H}_{2} \mathrm{O}$. The fluxes of individual species must be equal in magnitude and must have the common numerical value $1.3 \times 10^{10} \mathrm{~cm}^{-2} \mathrm{sec}^{-1}$. The downward flux of $\mathrm{CO}$ is approximately equal to $0.1 \%$ of the total photolytic production of $\mathrm{CO}$. Fluxes of this magnitude are readily transported vertically, provided that the vertical eddy coefficient ${ }^{1}$ is greater than about $10^{4} \mathrm{~cm}^{2} \mathrm{sec}^{-1}$. The chemical cycle should be completed in the hot lower

1 This value was derived under the assumption that the mixing ratio of $\mathrm{H}_{2}$ was approximately $10^{-7}$. Note also, as discussed later, that a consideration of $\mathrm{O}_{2}$ chemistry reinforces the conclusion that the eddy coefficient must exceed $10^{4} \mathrm{~cm}^{2} \sec ^{-1}$.

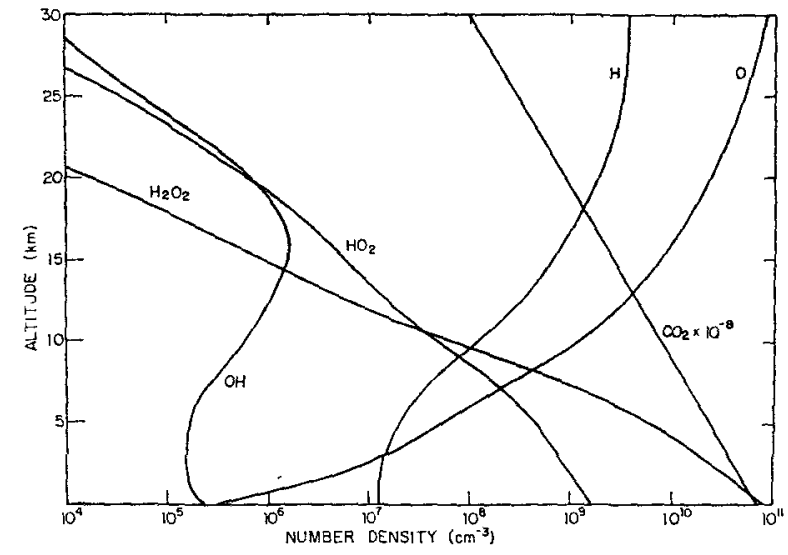

FIG. 2. Concentrations of $\mathrm{H}, \mathrm{OH}, \mathrm{HO}_{2}, \mathrm{H}_{2} \mathrm{O}_{2}, \mathrm{O}$ and $\mathrm{CO}_{2}$ for the dry model.

atmosphere where there should be efficient conversion of $\mathrm{CO}$ and $\mathrm{H}_{2} \mathrm{O}$ to $\mathrm{CO}_{2}$ and $\mathrm{H}_{2}$ in the global reaction

$$
\mathrm{CO}+\mathrm{H}_{2} \mathrm{O} \rightarrow \mathrm{CO}_{2}+\mathrm{H}_{2} \text {. }
$$

The time constant associated with (29) can be readily estimated using data presented by Graven and Long (1954). The effective rate constant $\left(\mathrm{cm}^{3} \mathrm{sec}^{-1}\right)$ is given approximately by

$$
k_{29}=2 \times 10^{2} \exp (-67.3 / R T)[\mathrm{CO}]^{-\frac{1}{3}}
$$

and the time constant associated with (29) is approximately $2 \times 10^{8} \mathrm{sec}$ at the surface of Venus if the mixing ratios of $\mathrm{H}_{2} \mathrm{O}$ and $\mathrm{CO}$ are taken equal to $8.8 \times 10^{-5}$. On the other hand, the time constant associated with the downward flux of $\mathrm{CO}$ and $\mathrm{H}_{2} \mathrm{O}$ from the upper atmosphere is much longer, approximately $10^{13} \mathrm{sec}$. It follows that the downward flux should introduce a trivial perturbation to conditions in the lower atmosphere, and the relative concentrations of $\mathrm{CO}, \mathrm{CO}_{2}, \mathrm{H}_{2}$ and $\mathrm{H}_{2} \mathrm{O}$ should be consistent with thermodynamic equilibrium.

We can now estimate the mixing ratio of $\mathrm{H}_{2}$. If we assume that the relative concentrations of $\mathrm{CO}, \mathrm{CO}_{2}, \mathrm{H}_{2}$

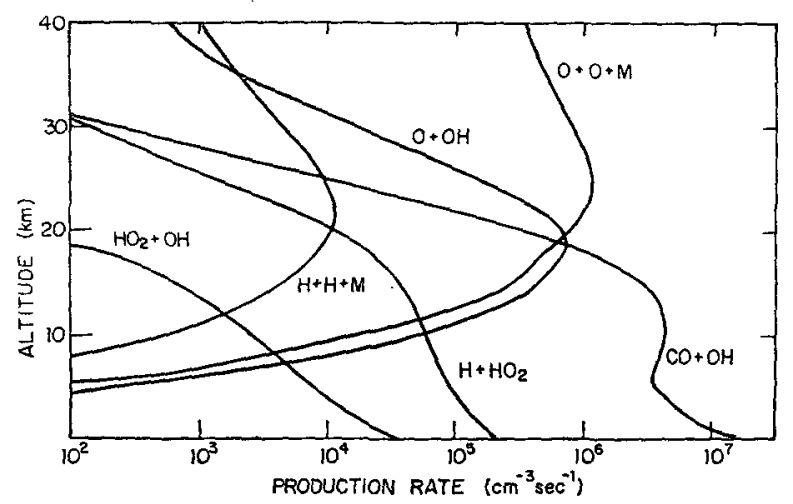

FIG. 3. Production rates for key reactions leading to production of $\mathrm{H}_{2}\left(\mathrm{H}+\mathrm{H}+\mathrm{M}\right.$ and $\left.\mathrm{H}+\mathrm{HO}_{2}\right), \mathrm{O}_{2}(\mathrm{O}+\mathrm{OH}$ and $\mathrm{O}+\mathrm{O}+\mathrm{M})$, $\mathrm{CO}_{2}(\mathrm{CO}+\mathrm{OH})$ and $\mathrm{H}_{2} \mathrm{O}\left(\mathrm{HO}_{2}+\mathrm{OH}\right)$, in the dry model. 


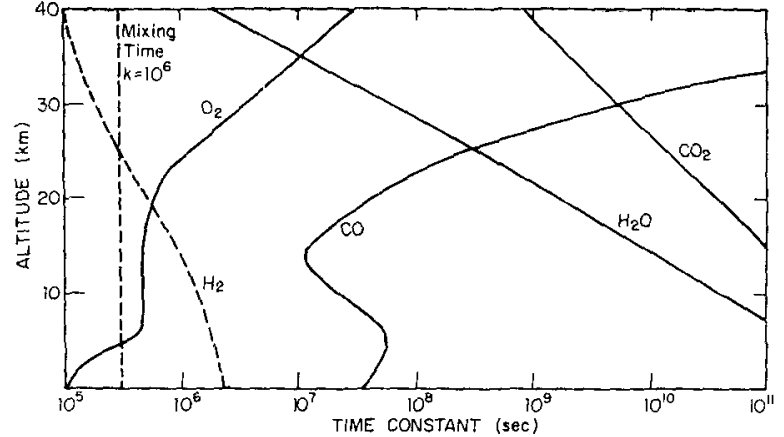

FIG. 4. Time constants in the dry model, for chemical removal of $\mathrm{CO}, \mathrm{CO}_{2}, \mathrm{H}_{2}$ and $\mathrm{H}_{2} \mathrm{O}$. The dynamical time constant for an assumed eddy diffusion coefficient $K=10^{6} \mathrm{~cm}^{2} \mathrm{sec}^{-1}$ is included for comparison.

and $\mathrm{H}_{2} \mathrm{O}$ are controlled by (29) and its inverse, then

$$
f_{\mathrm{H}_{2}}=K f_{\mathrm{H}_{2} \mathrm{O}} f_{\mathrm{CO}} \text {, }
$$

where $K$ is the appropriate equilibrium constant. Using data presented in the Janaf tables we find

$$
f_{\mathrm{H}_{2}}=7 \times 10^{-8} \text {, }
$$

if

$$
f_{\mathrm{CO}}=f_{\mathrm{E}_{2} \mathrm{O}}=8.8 \times 10^{-5} \text {. }
$$

Chemical time constants for long-lived species ( $\mathrm{CO}$, $\mathrm{O}_{2}, \mathrm{CO}_{2}, \mathrm{H}_{2}, \mathrm{H}_{2} \mathrm{O}$ ) are illustrated in Fig. 4 ; corresponding data for short-lived species $\left(\mathrm{OH}, \mathrm{HO}_{2}, \mathrm{H}, \mathrm{O}, \mathrm{H}_{2} \mathrm{O}_{2}\right)$ are shown in Fig. 5. Fig. 5 also includes time constants for odd $\mathrm{H}$, odd $\mathrm{O}$ and free $\mathrm{Cl}$. The various time constants are defined in Appendix B. We note that the assumptions of the present model require that time constants in Fig. 4 must be long compared with time constants for vertical motion. In like manner, time constants in Fig. 5 must be short compared with dynamical times. For reference, we indicate in both Figs. 5 and 6 the dynamical time constants which would apply if vertical motion were characterized by an effective eddy coefficient $K=10^{6} \mathrm{~cm}^{2} \mathrm{sec}^{-1}$. If the eddy

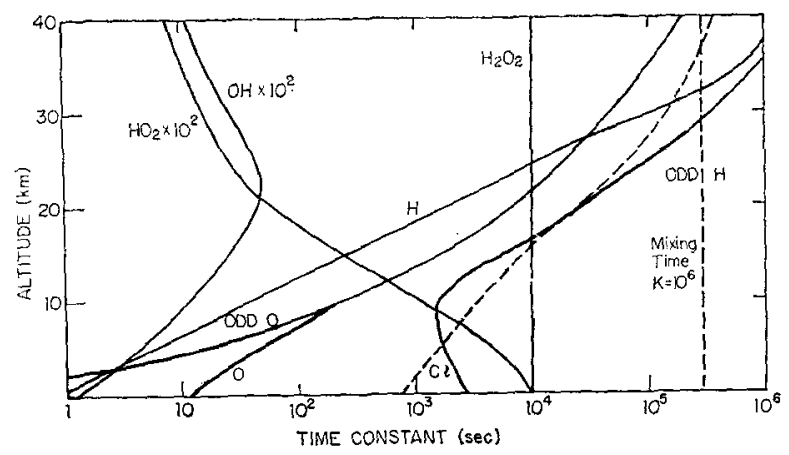

FIG. 5. Time constants in the dry model, for chemical removal of $\mathrm{H}, \mathrm{OH}, \mathrm{HO}_{2}, \mathrm{H}_{2} \mathrm{O}_{2}, \mathrm{O}$, odd $\mathrm{H}$, free $\mathrm{Cl}$ and odd $\mathrm{O}$. The dynamical time constant for an eddy coefficient $K=10^{6} \mathrm{~cm}^{2} \mathrm{sec}^{-1}$ is included for comparison. coefficient had this value, then the present analysis would be valid over the height range $5-27 \mathrm{~km}$. Odd hydrogen would be in dynamical equilibrium above $27 \mathrm{~km}$. The distribution of $\mathrm{O}_{2}$ below $5 \mathrm{~km}$ would be determined by a combination of chemistry and dynamics. Some small correction would be required for $\mathrm{H}$, $\mathrm{OH}$ and $\mathrm{HO}_{2}$ above $27 \mathrm{~km}$ but the correction would be generally trivial in the present context. The mixing ratio of $\mathrm{O}_{2}$ would be an increasing function of height between 0 and $5 \mathrm{~km}$, with a mean value of about $10^{-7}$. The mixing ratio of $\mathrm{O}_{2}$ at higher altitudes could be somewhat higher than this value.

If the eddy coefficient were less than $10^{6} \mathrm{~cm}^{2} \mathrm{sec}^{-1}$, a much larger correction would be required for lower altitude $\mathrm{O}_{2}$. Indeed, as discussed in Appendix $\mathrm{C}$, it would appear that physically acceptable solutions can be obtained only if the eddy coefficient exceeds $4 \times 10^{4}$ $\mathrm{cm}^{2} \mathrm{sec}^{-1}$ over the height range $0-6 \mathrm{~km}$. If the eddy coefficient were larger than $10^{6} \mathrm{~cm}^{2} \mathrm{sec}^{-1}$ then $\mathrm{O}_{2}$ should be well mixed throughout the atmosphere. The concentrations of odd $\mathrm{H}$ and odd $\mathrm{O}$ would require modification at higher altitudes. Production of $\mathrm{O}_{2}$ would be reduced, and the recombination path (1) would be relatively more important than (2). The mixing ratio of $\mathrm{O}_{2}$ would be lowered accordingly.

Computed number densities for $\mathrm{H}, \mathrm{OH}, \mathrm{HO}_{2}, \mathrm{H}_{3} \mathrm{O}_{2}$ and $\mathrm{O}$ are shown in Fig. 6 for the wet model. The mixing ratios of $\mathrm{CO}, \mathrm{H}_{2} \mathrm{O}, \mathrm{O}_{2}$ and $\mathrm{HCl}$ are $4.8 \times 10^{-5}, 4.8 \times 10^{-5}$, $7 \times 10^{-8}$ and $8 \times 10^{-7}$, respectively. The heightintegrated production rates for $\mathrm{CO}_{2}, \mathrm{O}_{2}, \mathrm{H}_{2}$ and $\mathrm{H}_{2} \mathrm{O}$ are, within tolerable limits, equal to the corresponding height integrated loss rates. The production rates are $1.1 \times 10^{13}, 3.2 \times 10^{12}, 2.5 \times 10^{11}$ and $3.7 \times 10^{10} \mathrm{~cm}^{-2} \mathrm{sec}^{-1}$ for $\mathrm{CO}_{2}, \mathrm{O}_{2}, \mathrm{H}_{2}$ and $\mathrm{H}_{2} \mathrm{O}$, respectively. Volume rates for several important reactions are shown in Fig. 7. As in the dry model, $\mathrm{O}_{2}$ is formed above $18 \mathrm{~km}$ by $k_{2}$ and $k_{8}$, and removed below $5 \mathrm{~km}$ by (2). Water is formed at low altitudes by $k_{11}$ and removed at the same rate at high altitudes by $J_{5}$. Molecular hydrogen is catalytically removed by $\mathrm{Cl}$ and reformed by $k_{10}$ and $k_{13}$.

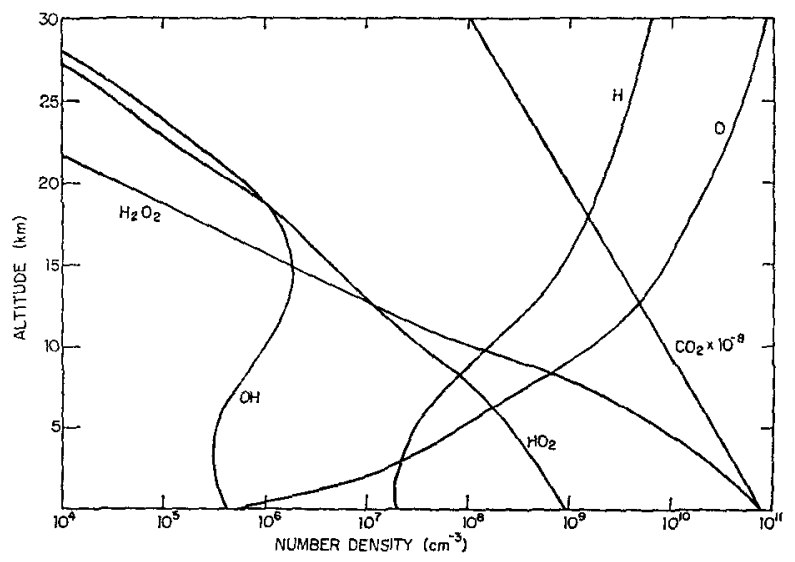

FIG. 6. Concentrations of $\mathrm{H}, \mathrm{OH}, \mathrm{HO}_{2}, \mathrm{H}_{2} \mathrm{O}_{2}, \mathrm{O}$ and $\mathrm{CO}_{2}$ for the wet model. 
Ozone is an exceedingly rare component in both wet and dry models. The column abundance is approximately $10^{-6} \mathrm{~cm}$ atm, with a peak concentration of about $3 \times 10^{7} \mathrm{~cm}^{-3}$ at $10 \mathrm{~km}$. The predicted concentration of $\mathrm{O}_{3}$ depends critically on the concentration of $\mathrm{O}_{2}$ above $10 \mathrm{~km}$. The prediction is thus sensitive to the value of the eddy mixing coefficient at low altitudes. If the eddy coefficient is less than $3 \times 10^{4} \mathrm{~cm}^{2} \mathrm{sec}^{-1}$, then the concentrations of $\mathrm{O}_{2}$, and therefore $\mathrm{O}_{3}$, will be larger than values derived here. The observational upper limit on $\mathrm{O}_{2}$ reported by Traub and Carleton (1973) could permit $\mathrm{O}_{3}$ concentrations as large as $10^{-4} \mathrm{~cm}$ atm. An observation of $\mathrm{O}_{3}$ would be valuable, and would provide useful information on the strength of atmospheric mixing in the lower stratosphere and upper troposphere of Venus.

\section{Concluding remarks}

We have presented a model for the photochemistry of the Venus atmosphere which satisfactorily accounts for the stability of $\mathrm{CO}_{2}$. The recombination path is similar to that believed appropriate for Mars and is catalyzed by trace hydrogenous species such as $\mathrm{H}, \mathrm{OH}$, $\mathrm{HO}_{2}$ and $\mathrm{H}_{2} \mathrm{O}_{2}$. Carbon monoxide is removed by

$$
\mathrm{CO}+\mathrm{OH} \rightarrow \mathrm{CO}_{2}+\mathrm{H},
$$

with $\mathrm{OH}$ formed either by

$$
\mathrm{O}+\mathrm{HO}_{2} \rightarrow \mathrm{OH}+\mathrm{O}_{2}
$$

or

$$
h \nu+\mathrm{H}_{2} \mathrm{O}_{2} \rightarrow 2 \mathrm{OH} \text {. }
$$

We did not explicitly treat possible catalysis of $\mathrm{CO}_{2}$ recombination by trace quantities of free chlorine. Prinn (1971) suggested that the dominant path for recombination of Venus $\mathrm{CO}_{2}$ might be

$$
\mathrm{Cl}+\mathrm{O}_{2}+\mathrm{CO}_{2} \rightarrow \mathrm{ClOO}+\mathrm{CO}_{2}
$$

followed by

$$
\mathrm{ClOO}+\mathrm{CO} \rightarrow \mathrm{ClO}+\mathrm{CO}_{2}
$$

and

$$
\mathrm{ClO}+\mathrm{CO} \rightarrow \mathrm{Cl}+\mathrm{CO}_{2}
$$

Omission of these reactions in the present context should not be interpreted to reflect a judgment regarding their possible importance. They were omitted primarily due to the lack of relevant laboratory data. ${ }^{2}$ Prinn's scheme could be important, however, and would proceed in addition to, but not in competition with, the hydrogenous scheme emphasized here. In particular, our estimates for the mixing ratio of $\mathrm{O}_{2}$ could be too high if (37)-(39) are found to be important for Venus.

\footnotetext{
${ }^{2} \mathrm{We}$ may note, however, that the reactions $\mathrm{CO}+\mathrm{HO}_{2} \rightarrow \mathrm{CO}_{2}$ $+\mathrm{OH}$ and $\mathrm{CO}+\mathrm{O}_{2} \rightarrow \mathrm{CO}_{2}+\mathrm{O}$ which are to some extent analogous to (38) are, in fact, negligibly slow at temperatures of interest in the present study. Analogy would support the notion that reactions (37), (39) and (40) should be rapid and suggests that $\mathrm{Cl}$ may indeed catalyze recombination of $\mathrm{CO}$ and $\mathrm{O}$, if not $\mathrm{CO}$ and $\mathrm{O}_{2}$, in the Venus atmosphere.
}

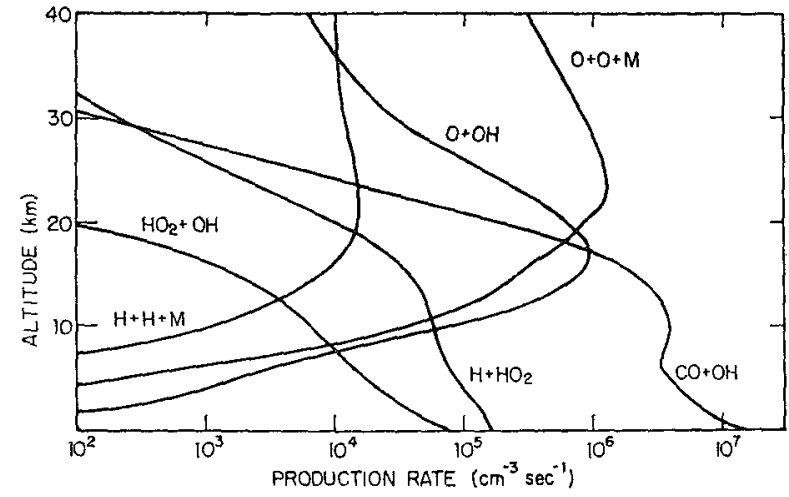

Fis. 7. Production rates $\left(\mathrm{cm}^{-3} \mathrm{sec}^{-1}\right)$ for key reactions leading to production of $\mathrm{H}_{2}\left(\mathrm{H}+\mathrm{H}+\mathrm{M}\right.$ and $\left.\mathrm{H}+\mathrm{HO}_{2}\right), \mathrm{O}_{2}(\mathrm{O}+\mathrm{OH}$ and $\mathrm{O}+\mathrm{O}+\mathrm{M}), \mathrm{CO}_{2}(\mathrm{CO}+\mathrm{OH})$ and $\mathrm{H}_{2} \mathrm{O}\left(\mathrm{HO}_{2}+\mathrm{OH}\right)$, in the wet model.

Free chlorine can also catalyze recombination of $\mathrm{CO}$ and $O$. The reaction sequence (37) followed by

$$
\mathrm{ClOO}+\mathrm{O} \rightarrow \mathrm{ClO}+\mathrm{O}_{2}
$$

and (39) offers a recombination path which could proceed in addition to (1) and which might be important below about $10 \mathrm{~km}$. Some indirect support for (37) and (40) can be obtained from a laboratory study of oxygen recombination in the presence of $\mathrm{Cl}_{2}$. Kaufman (1958) concluded that his data could be understood if (40) were fast, and if the rate constant for (37) were of order $10^{-31} \mathrm{~cm}^{6} \mathrm{sec}^{-1}$. There is, however, no direct evidence for the reactions with $\mathrm{CO}_{2}$ and $\mathrm{CO}$, although other chlorine reactions have been involved in a variety of contexts as discussed by Kaufman (1958). If it turns out that (37), (39) and (40) are indeed important, then densities of atomic oxygen and ozone will be less than values computed in the present paper at altitudes below about $10 \mathrm{~km}$. Other features of the present work would be unaltered, however. In particular, dissociation of $\mathrm{CO}_{2}$ above $20 \mathrm{~km}$ would still be expected to lead mainly to formation of $\mathrm{O}_{2}$ which must be removed by (2) and its chlorine equivalent (37)- (39).

The mixing ratio of $\mathrm{O}_{2}$ in the vicinity of the Venus cloud deck must be small, of order $10^{-7}$ or less. Otherwise, dissociation of $\mathrm{HCl}$ and subsequent chemistry would lead to production of unacceptably large quantities of $\mathrm{H}_{2} \mathrm{O}$. Our predictions for $\mathrm{O}_{2}$ are consistent with the observational limit imposed by Traub and Carleton (1973). We noted, however, that $\mathrm{O}_{2}$ may not be homogeneously mixed with $\mathrm{CO}_{2}$ throughout the upper atmosphere of Venus.

The abundance of $\mathrm{H}_{2} \mathrm{O}$ in the atmosphere of Venus is uncertain. We argued that $\mathrm{H}_{2} \mathrm{O}$ must be at least as abundant as $\mathrm{CO}$ in the bulk of the atmosphere and most of the Venus $\mathrm{H}_{2} \mathrm{O}$ could be formed as a by-product of upper atmospheric chemistry.

The present work should impose important constraints on attempts to model the chemistry of sulphur in the atmosphere of Venus, a matter of importance in 
view of the recent suggestion by Young (1973) regarding the composition of the clouds. The rate for formation of $\mathrm{H}_{2} \mathrm{SO}_{4}$ may be limited by the available supply of $\mathrm{O}_{2},{ }^{3}$

Acknowledgments. This work was supported by the Atmospheric Sciences Division of the National Science Foundation under Grant GA33990X to Harvard University. We thank the Harvard High Energy Group for permission to use their computer (on a low priority basis, of course) for the low energy research described here. The computer is supported by AEC Contract AT (11-1)-3064. We are indebted to Mark Rosen for helpful comments.

\section{APPENDIX $A$}

\section{The Chemical Model}

The detailed chemical model adopted for present purposes is summarized in Table 2. We assume that chemical equilibrium holds for $\mathrm{Cl}, \mathrm{Cl}_{2}, \mathrm{H}, \mathrm{OH}, \mathrm{HO}_{2}$, $\mathrm{H}_{2} \mathrm{O}_{2}$ and $\mathrm{O}$. Then

$$
\begin{aligned}
& J_{4}[\mathrm{HCl}]+2 J_{7}\left[\mathrm{Cl}_{2}\right] \\
& =2 k_{15}[\mathrm{Cl}] 2\left[\mathrm{CO}_{2}\right]+k_{1+}[\mathrm{Cl}]\left[\mathrm{H}_{2}\right] \text {, } \\
& k_{15}[\mathrm{Cl}] 2\left[\mathrm{CO}_{2}\right]=J_{7}\left[\mathrm{Cl}_{2}\right] \text {, } \\
& k_{5}[\mathrm{CO}][\mathrm{OH}]+k_{8}[\mathrm{O}][\mathrm{OH}]+2 J_{4}[\mathrm{HCl}]+J_{5}\left[\mathrm{H}_{2} \mathrm{O}\right] \\
& =k_{3}[\mathrm{H}]\left[\mathrm{O}_{2}\right]\left[\mathrm{CO}_{2}\right]+\left(k_{10}+k_{12}\right)[\mathrm{H}]\left[\mathrm{HO}_{2}\right] \\
& +2 k_{13}[\mathrm{H}] 2\left[\mathrm{CO}_{2}\right] \text {, } \\
& +k_{8}[\mathrm{O}][\mathrm{OH}] \\
& k_{3}[\mathrm{H}]\left[\mathrm{O}_{2}\right]\left[\mathrm{CO}_{2}\right] \\
& =\left(k_{10}+k_{12}\right)[\mathrm{H}]\left[\mathrm{HO}_{2}\right]+k_{11}[\mathrm{OH}]\left[\mathrm{HO}_{2}\right] \\
& +2 k_{9}\left[\mathrm{HO}_{3}\right]^{2}+k_{4}[\mathrm{O}]\left[\mathrm{HO}_{2}\right] \text {, } \\
& k_{9}\left[\mathrm{HO}_{2}\right]^{2}=J_{6}\left[\mathrm{H}_{2} \mathrm{O}_{2}\right] \text {, } \\
& 2 J_{2}\left[\mathrm{O}_{2}\right]+J_{1}\left[\mathrm{CO}_{2}\right] \\
& =2 k_{2}[\mathrm{O}]^{2}\left[\mathrm{CO}_{2}\right]+k_{4}[\mathrm{O}]\left[\mathrm{HO}_{2}\right]+k_{8}[\mathrm{O}][\mathrm{OH}] \text {. }
\end{aligned}
$$

We can combine (A1), (A2) to give (11), where

$$
p(\mathrm{HCl})=k_{14}[\mathrm{Cl}]\left[\mathrm{H}_{2}\right]-J_{4}[\mathrm{HCl}] \text {. }
$$

3 Note added in proof. The dry model in this paper requires some net conversion of $\mathrm{H}_{2} \mathrm{O}$ to $\mathrm{H}_{2}$ through the global reaction (6) at the planetary surface. Taking a value $10^{-10} \mathrm{~cm}^{3} \mathrm{sec}^{-1}$ for $k_{11}$ we estimate that the magnitude of the downward flux of $\mathrm{H}_{2} \mathrm{O}$, and consequently the upward flux of $\mathrm{H}_{2}$, should be $1.3 \times 10^{10} \mathrm{~cm}^{-2}$ $\sec ^{-1}$. It appears now that this value may be too low. Recent laboratory work by G. A. Takucs and G. P. Glass (J. Phys. Chem., 77, p. 1948) suggests that the reaction

$$
\mathrm{OH}+\mathrm{HCl} \rightarrow \mathrm{H}_{2} \mathrm{O}+\mathrm{Cl}
$$

may provide a significant source of atmospheric $\mathrm{H}_{2} \mathrm{O}$ in addition to that derived from

$$
\mathrm{OH}+\mathrm{HO}_{2} \rightarrow \mathrm{H}_{2} \mathrm{O}+\mathrm{O}_{2} .
$$

After including this additional path for $\mathrm{H}_{2} \mathrm{O}$ production, we find that the downward flux of $\mathrm{H}_{2} \mathrm{O}$ is increased to $6 \times 10^{10} \mathrm{~cm}^{-2} \mathrm{sec}^{-1}$. Other features of the dry model remain essentially unchanged. A balance can be obtained in the wet model, allowing for the new source of $\mathrm{H}_{2} \mathrm{O}$, if we take the mixing ratios of $\mathrm{CO}, \mathrm{O}_{2}, \mathrm{H}_{2} \mathrm{O}$ and $\mathrm{HCl}$ as $7.8 \times 10^{-5}, 5.0 \times 10^{-8}, 1.8 \times 10^{-4}$ and $9 \times 10^{-7}$, respectively.
Similarly (A3), (A4) and (A5) can be combined to give (9) with

$$
\begin{aligned}
p\left(\mathrm{H}_{2}\right) & =k_{10}[\mathrm{H}]\left[\mathrm{HO}_{2}\right]+k_{13}[\mathrm{H}]^{2}\left[\mathrm{CO}_{2}\right] \\
& -J_{4}[\mathrm{HCl}] \\
p\left(\mathrm{H}_{2} \mathrm{O}\right) & =k_{11}[\mathrm{OH}]\left[\mathrm{HO}_{2}\right]-J_{5}\left[\mathrm{H}_{2} \mathrm{O}\right] .
\end{aligned}
$$

In like manner (A4) and (A5) imply (10) with

$$
\begin{aligned}
p\left(\mathrm{CO}_{2}\right) & =k_{5}[\mathrm{CO}][\mathrm{OH}]-J_{1}\left[\mathrm{CO}_{2}\right], \\
p\left(\mathrm{O}_{2}\right) & =k_{2}\left[\mathrm{O}^{2}\left[\mathrm{CO}_{2}\right]+k_{8}[\mathrm{O}][\mathrm{OH}]-k_{9}\left[\mathrm{HO}_{2}\right]^{2}\right. \\
& -J_{2}\left[\mathrm{O}_{2}\right]-k_{12}[\mathrm{H}]\left[\mathrm{HO}_{2}\right] .
\end{aligned}
$$

Reactions involving $\mathrm{O}_{3}$ are generally unimportant for Venus, and have been omitted in Eqs. (A1)-(A11). These reactions were, however, included in the detailed numerical calculations described earlier in this paper. We introduce here a number of additional approximations in order to provide a simple analytic framework for interpretation of the detailed numerical results. Below $6 \mathrm{~km}$ the relative concentrations of $\mathrm{H}, \mathrm{OH}$ and $\mathrm{HO}_{2}$ are controlled by $k_{3}, k_{4}, k_{5}, k_{9}, k_{12}$ and $J_{6}$. Above $8 \mathrm{~km}$, the relative concentrations of $\mathrm{H}, \mathrm{OH}, \mathrm{HO}_{2}$ and $\mathrm{O}$ are controlled by $k_{3}, k_{4}$ and $k_{8}$.

Below $20 \mathrm{~km}$, we have

$\frac{[\mathrm{OH}]}{[\mathrm{H}]}=\frac{k_{3}\left[\mathrm{O}_{2}\right]\left[\mathrm{CO}_{2}\right]+k_{12}\left[\mathrm{HO}_{2}\right]}{k_{5}[\mathrm{CO}]} \approx \frac{k_{3}\left[\mathrm{O}_{2}\right]\left[\mathrm{CO}_{2}\right]}{k_{5}[\mathrm{CO}]}$.

Below $6 \mathrm{~km}$, we have

$$
k_{12}[\mathrm{H}]+k_{4}[\mathrm{O}] \ll 2 k_{9}\left[\mathrm{HO}_{2}\right] \text {. }
$$

Thus

$$
\frac{\left[\mathrm{HO}_{2}\right]^{2}}{[\mathrm{OH}]} \approx \frac{k_{5}[\mathrm{CO}]}{2 k_{9}} .
$$

Above $6 \mathrm{~km}$ we have (A14) in the reverse direction and

$$
\frac{\left[\mathrm{HO}_{2}\right]}{[\mathrm{OH}]} \approx \frac{k_{5}[\mathrm{CO}]}{k_{12}[\mathrm{H}]+k_{4}[\mathrm{O}]} .
$$

If $k_{11}[\mathrm{OH}] / k_{10}[\mathrm{H}] \ll 1$, that is, if

$$
\frac{f_{\mathrm{O}_{2}}}{f_{\mathrm{CO}}} \ll \frac{k_{5} k_{10}}{k_{11} k_{3}\left[\mathrm{CO}_{2}\right]}
$$

where $f_{\mathrm{O}_{2}, \mathrm{CO}}$ are mixing ratio of $\mathrm{O}_{2}$ and $\mathrm{CO}$, respectively, then the equation for odd $\mathrm{H}$ is simply

$$
k_{10}[\mathrm{H}]\left[\mathrm{HO}_{2}\right] \approx J_{5}\left[\mathrm{H}_{2} \mathrm{O}\right]+J_{4}[\mathrm{HCl}] \text {. }
$$

Expressions (14)-(16) can be readily derived using (A13), (A15) and (A17); expressions (17)-(20), which are appropriate in the height range $6-18 \mathrm{~km}$, can be derived using (A13), (A15'), (A17) and (A7). The bulk of the total $\mathrm{CO}$ recombination in the Venus atmosphere 
occurs below $18 \mathrm{~km}$ and is satisfactorily approximated by (26) and (27). Note that recombination of $\mathrm{CO}$ below $20 \mathrm{~km}$ is essentially independent of the value for the mixing ratio of $\mathrm{CO}$.

We consider now the alternate case in which $\mathrm{H}$ recombination leads to production of $\mathrm{H}_{2} \mathrm{O}$. In this case we have

$$
k_{11} k_{3} f_{\mathrm{O}_{2}}\left[\mathrm{CO}_{2}\right] \gg k_{5} k_{10} f_{\mathrm{CO}} \text {. }
$$

As before, the expressions for $[\mathrm{H}],[\mathrm{OH}]$ and $\left[\mathrm{HO}_{2}\right]$ assume different limiting forms depending on whether $\mathrm{HO}_{2}$ is cycled by $k_{7}$ or $k_{4}+k_{12}$. In the first case we have

$$
\begin{aligned}
& \left.[\mathrm{HO})_{2}\right]=\left\{\frac{k_{5}[\mathrm{CO}]\left(J_{5}\left[\mathrm{H}_{2} \mathrm{O}\right]+J_{4}[\mathrm{HCl}]\right)}{2 k_{9} k_{11}}\right\}^{\frac{1}{3}}, \\
& {[\mathrm{H}]=\frac{2^{\frac{1}{3}} k_{9}{ }^{3} k_{5}{ }^{3}[\mathrm{CO}]^{3}\left(J_{5}\left[\mathrm{H}_{2} \mathrm{O}\right]+J_{4}[\mathrm{HCl}]^{\frac{3}{3}}\right.}{k_{11^{3}} k_{3}\left[\mathrm{O}_{2}\right]\left[\mathrm{CO}_{2}\right]},} \\
& {[\mathrm{OH}]=\frac{2^{3} k_{9}{ }^{3}\left(J _ { 5 } \left[\mathrm{H}_{2} \mathrm{O}+J_{4}[\mathrm{HCl})^{\frac{3}{3}}\right.\right.}{k_{11}{ }^{3} k_{5}{ }^{3}[\mathrm{CO}]^{\frac{1}{3}}} .}
\end{aligned}
$$

In the second case

$$
\begin{aligned}
& {\left[\mathrm{HO}_{2}\right]=\frac{k_{5}[\mathrm{CO}]\left\{J_{4}[\mathrm{HCl}]+J_{5}\left[\mathrm{H}_{2} \mathrm{O}\right]\right\}}{k_{11} J_{1}\left[\mathrm{CO}_{2}\right]},} \\
& {[\mathrm{H}]=\frac{J_{1}\left[\mathrm{CO}_{2}\right]}{k_{3}\left[\mathrm{O}_{2}\right]\left[\mathrm{CO}_{2}\right]},} \\
& {[\mathrm{OH}]=\frac{J_{1}\left[\mathrm{CO}_{2}\right]}{k_{5}[\mathrm{CO}]},} \\
& {[\mathrm{O}]=\frac{k_{11}\left\{J_{1}\left[\mathrm{CO}_{2}\right]\right\}^{2}}{k_{4} k_{5}[\mathrm{CO}]\left\{J_{4}[\mathrm{HCl}]+J_{5}\left[\mathrm{H}_{2} \mathrm{O}\right]\right\}} .}
\end{aligned}
$$

As before, (A23)-(A25) are valid mainly below $6 \mathrm{~km}$ and (A26)-(A29) apply between $6 \mathrm{~km}$ and $18 \mathrm{~km}$. The corresponding expressions for the $\mathrm{CO}$ recombination

rate are

$R(\mathrm{CO})=2^{\frac{1}{3}} k_{5^{\frac{\pi}{2}}}^{\frac{\pi}{2}} k_{9}^{\frac{1}{3}} k_{11}-\frac{3}{2}[\mathrm{CO}]^{\frac{1}{3}}\left(J_{i}\left[\mathrm{H}_{2} \mathrm{O}\right]+J_{4}[\mathrm{HCl}]\right)^{\frac{2}{3}}$,

$R(\mathrm{CO})=J_{1}\left[\mathrm{CO}_{2}\right]$

Above $20 \mathrm{~km}, k_{\bar{n}}[\mathrm{CO}]<k_{8}[\mathrm{O}]$, and the relative concentrations of $\mathrm{H}, \mathrm{OH}$ and $\mathrm{HO}_{2}$ are controlled by $k_{3}, k_{4}$ and $k_{8}$. Then

$$
\begin{aligned}
& \frac{[\mathrm{OH}]}{[\mathrm{H}]}=\frac{k_{3}\left[\mathrm{O}_{2}\right]\left[\mathrm{CO}_{2}\right]}{k_{8}[\mathrm{O}]}, \\
& \frac{[\mathrm{OH}]}{\left[\mathrm{HO}_{2}\right]}=\frac{k_{4}}{k_{8}},
\end{aligned}
$$

and

$$
k_{13}[\mathrm{H}]\left[\mathrm{CO}_{2}\right] \approx J_{4}[\mathrm{HCl}]+J_{5}\left[\mathrm{H}_{2} \mathrm{O}\right] .
$$

The photochemical equations can now be solved to give the approximate results given by (21)-(24) which are identical in both wet and dry models.

The rate for recombination of $\mathrm{CO}$ is given by (27) and

$$
\begin{gathered}
R\left(\mathrm{O}_{2}\right) \approx \frac{1}{2} J_{1}\left[\mathrm{CO}_{2}\right] . \\
\text { APPENDIX B } \\
\text { Time Constants }
\end{gathered}
$$

The time constants for $\mathrm{CO}_{2}, \mathrm{CO}, \mathrm{H}_{2} \mathrm{O}, \mathrm{O}, \mathrm{H}, \mathrm{OH}$, $\mathrm{HO}_{2}$ and $\mathrm{H}_{2} \mathrm{O}_{2}$ can be calculated in the usual way. The time constants for $\mathrm{O}_{2}, \mathrm{H}_{2}$, odd $\mathrm{O}$, odd $\mathrm{H}$ and $\mathrm{Cl}$ are calculated from the following expressions:

$$
\begin{aligned}
\tau_{\mathrm{O}_{2}} & =\frac{\left[\mathrm{O}_{2}\right]}{k_{9}\left[\mathrm{HO}_{2}\right]^{2}+k_{12}[\mathrm{H}]\left[\mathrm{HO}_{2}\right]} \\
\tau_{\mathrm{H}_{2}} & =\frac{\left[\mathrm{H}_{2}\right]}{J_{4}[\mathrm{HCl}]} \\
\tau_{\text {odd } \mathrm{O}} & =\frac{[\mathrm{O}]+[\mathrm{OH}]}{2 k_{2}[\mathrm{O}]^{2}\left[\mathrm{CO}_{2}\right]+k_{5}[\mathrm{OH}][\mathrm{CO}]+2 k_{8}[\mathrm{OH}][\mathrm{O}]+k_{11}[\mathrm{OH}]\left[\mathrm{HO}_{2}\right]} \\
\tau_{\text {odd } \mathrm{H}} & =\frac{[\mathrm{H}]+[\mathrm{OH}]+\left[\mathrm{HO}_{2}\right]}{2 k_{10}[\mathrm{H}]\left[\mathrm{HO}_{2}\right]+2 k_{11}[\mathrm{OH}]\left[\mathrm{HO}_{2}\right]+2 k_{13}[\mathrm{H}]^{2}\left[\mathrm{CO}_{2}\right]} \\
\tau_{\mathrm{Cl}} & =\frac{1}{k_{14}\left[\mathrm{H}_{2}\right]^{\circ}}
\end{aligned}
$$

In these calculations $f_{\mathrm{H}_{2}}$ is taken to be $7.5 \times 10^{-8}$ as estimated from thermodynamic equilibrium on the surface of Venus. 


\section{APPENDIX C}

\section{Molecular Oxygen}

The concentration of $\mathrm{O}_{2}$ is given by

$$
\begin{aligned}
& \frac{d \phi}{d z}=p-L n, \\
& \phi=-K\left(\frac{d n}{d z}+\frac{n}{T} \frac{d T}{d z}+\frac{n}{H_{\mathrm{av}}}\right),
\end{aligned}
$$

where $\phi, n$ are the fiux and number density of $\mathrm{O}_{2}$.

In order to analytically approximate the solution we take

$$
\left.\begin{array}{l}
p=0 \\
L=\tau_{c}^{-1}=5 \times 10^{-6} \sec ^{-1}
\end{array}\right\}
$$

where $\tau_{c}$ is the mean chemical time constant for $\mathrm{O}_{2}$ in the height range $0-6 \mathrm{~km}$ where $\mathrm{O}_{2}$ may not be well mixed. Little error is introduced by this procedure.

The boundary conditions appropriate for the present context are

$$
\left.\begin{array}{l}
\phi(z=6 \mathrm{~km})=-3 \times 10^{12} \mathrm{~cm}^{-2} \mathrm{sec}^{-1} \\
n(z=0 \mathrm{~km})=10^{-7} \times\left[\mathrm{CO}_{2}\right]
\end{array}\right\} .
$$

The condition on $\phi$ is set by the column production rate of $\mathrm{O}_{2}$ above $18 \mathrm{~km}$. The condition on $n$ is set by the requirement that we should have an overall balance for various species. Solutions for various $K$ are shown in Fig. 8. Acceptable solutions must have $\phi<0$ or $d f_{\mathrm{O}_{2}} / d z>0$ over the height range of interest. It follows that consistent $\mathrm{O}_{2}$ profiles are obtained only for $K>4 \times 10^{4} \mathrm{~cm}^{2} \mathrm{sec}^{-1}$.

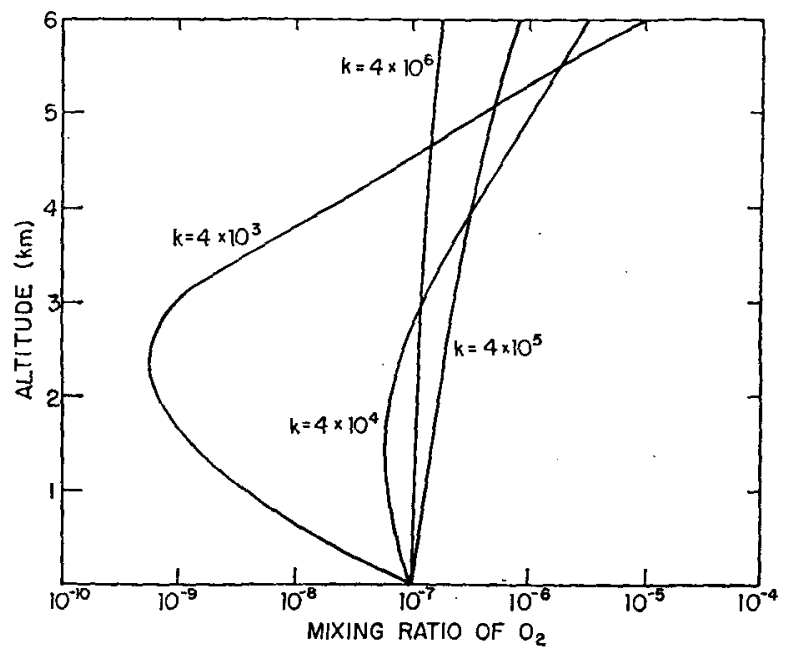

FIG. 8. Mixing ratios of $\mathrm{O}_{2}$ for various eddy coefficients.

\section{REFERENCES}

Avduevsky, V. S., M. Ya. Marov and M. K. Rozhdestvensky, 1970: A tentative model of the Venus atmosphere based on the measurements of Veneras 5 and 6. J.Atmos. Sci., 27, 561-568.

Bader, L. W., and E. A. Ogryzlo, 1964: Recombination of chlorine atoms. Nature, 201, 491-492.

Baulch, D. L., D. D. Drysdale and A. C. Lloyd, 1969: High Temperature Reaction Rate Data, 3, 18.

Berge, G. L., and E. W. Greisen, 1969: High-resolution interferometry of Venus at $3.12 \mathrm{~cm}$ wavelength. Asirophys. $J ., 156$, $1125-1134$

Brinkmann, R. T., A. E. S. Green and C. A. Barth, 1966: A digitalized solar ultraviolet spectrum. NASA Tech. Rept. 32-951.

Connes, P., J. Connes, W. S. Benedict and L. D. Kaplan, 1967: Traces of $\mathrm{HCl}$ and $\mathrm{HF}$ in the atmosphere of Venus. Astrophys. $J ., 147,1230-1237$.

Dainton, F. S., and P. B. Ayscough, 1967: Gaseous Photochlorination: Pholochemisiry and Reaction Kinetics. Cambridge University Press, 64-92.

Detwiler, C. R., D. L. Garett, J. D. Purcell and R. Tousey, 1961 : The intensity distribution in the ultraviolet solar spectrum. Ann. Géophys., 17, 9-18.

Fink, U., H. P. Larsen, G. P. Kuiper and R. F. Poppen, 1972: Water vapor in the atmosphere of Venus. Icarus, 17, 617-631.

Graven, W. M., and F. J. Long, 1954: Kinetics and mechanism of the two opposing reactions of the equilibrium $\mathrm{CO}+\mathrm{H}_{2} \mathrm{O}$ $=\mathrm{CO}_{2}+\mathrm{H}_{2}$. J. Amer. Chem. Soc., 76, 2602-2607.

Handbook of Geoplyysics and Space Environments, S. L. Valley, Ed., 1965: Air Force Cambridge Research Laboratory.

Hochanadel, C. J., J. A. Ghormley and P. J. Orgren, 1972: Absorption spectrum and reaction kinetics of the $\mathrm{HO}_{2}$ radical in the gas phase. J. Chem. Phys., 56, 4426-4432.

Inn, E. C. Y., and J. M. Heimerl, 1971: The photolysis of $\mathrm{CO}_{2}$ at wavclengths excecding $1740 \AA$. J. Atmos. Sci., 28, 838841 .

Janaf Thermodynamical Tables, 1965: Compiled by Dow Chemical Co., Midland, Mich., under PB-168370 (Clearinghouse for Federal Scientific and Technical Information).

Janssen, M. A., R. E. Hills, D. C. Thorton and W. J. Welch, 1973: Venus: New microwave measurements show no atmospheric water vapor. Science, 179, 994-996.

Kaufman, F., 1958: The air afterglow and its uses in the study of some reactions of atomic oxygen. Proc. Roy. Soc. London, A247, 123-139.

$\ldots, 1964:$ Aeronomic reactions involving hydrogen: A review of recent laboratory studies. Ann. Géophys., 20, 106-114.

_- 1969: Elementary gas reactions. Annual Reviews of Physical Chemistry, Vol. 20, Annual Reviews, Inc., Palo Alto, 45-90.

Larkin, F. S., and B. A. Thrush, 1964: Recombination of hydrogen atoms in the presence of atmospheric gas. Disc. Faraday Soc., 37, 112-117.

McElroy, M. B., and T. M. Donahue, 1972: Stability of the Martian atmosphere. Science, 177, 986-988.

NASA, 1972: Pioneer Venus. Report of a study by the Science Steering Group.

Parkinson, T. D., and D. M. Huntèn, 1972: Spectroscopy and aeronomy of $\mathrm{O}_{2}$ on Mars. J. Atmos. Sci., 29, 1380-1390.

Prinn, R. G., 1971: Photochemistry of $\mathrm{HCl}$ and other minor constituents in the atmosphere of Venus. J. Atmos. Sci., 28, 1058-1068.

Reeves, R. R., G. Manella and P. Harteck, 1960: Rate of recombination of oxygen atoms. J. Chem. Phys., 32, 632-633.

Rogers, A. E. E., R. P. Ingalls and L. P. Rainville, 1972: The topography of a swath around the equator from the wavelength dependence of the radar cross section. Astron. $J ., 77$, $100-103$.

Romand, J., and B. Vodar, 1948: Spectre d'absorption de l'acide chlorhydrique gazeaux dans la région de Schumann. Compl. Rend., 226, 238-240. 
Schofield, K., 1967: An evaluation of kinetic rate data for reactions of neutrals of atmospheric interest. Planetary Space Sci., 15, 643-670.

Schultz, E. D., and A. C. Holland, 1963: The solar flux incident at the top of the atmospheres of earth and neighboring planets for the spectral range $50 \AA$ to $3000 \AA$. NASA CR-11, Washington, D. C.

Seery, D. J., and D. Britton, 1964: The continuous absorption spectra of $\mathrm{Cl}_{2}, \mathrm{Br}_{2}, \mathrm{BrCl}, \mathrm{ICL}$ and IBr. J. Phys. Chem., 68, 2263-2266.

Shemansky, D. E., 1972: $\mathrm{CO}_{2}$ extinction coefficient $1700-3000 \AA$. J. Chem. Phys., 56, 1582-1587.

Simonaites, R., and J. Heicklen, 1972: Kinetics and mechanisms of the reaction of $\mathrm{O}\left({ }^{3} \mathrm{P}\right)$ with carbon monoxide, $J$. Chem. Phys., 56, 2004-2011.

Sinclair, A. C. E., J. P. Basart, D. Buhl and W. A. Gale, 1972: Precision interferometric observations of Venus at $11.1 \mathrm{~cm}$ wavelength. Astrophys. $J$., 175, 555-572.

Thompson, B. A., P. Harteck and R. R. Reeves, 1963: Ultraviolet absorption coefficients of $\mathrm{CO}_{2}, \mathrm{CO}, \mathrm{O}_{2}, \mathrm{H}_{2} \mathrm{O}, \mathrm{N}_{2} \mathrm{O}, \mathrm{NH}_{3}$,
$\mathrm{NO}, \mathrm{SO}_{2}$, and $\mathrm{CH}_{4}$ between 1850 and $4000 \AA . J$. Geophys. Res., 68, 6431-6436.

Traub, W. A., and N. P. Carleton, 1973: A search for $\mathrm{H}_{2} \mathrm{O}$ and $\mathrm{O}_{2}$ on Venus. Paper presented at American Astronomical Society Third Annual Meeting, Tucson, Ariz.

Vinogradov, A. P., Yu. A., Surkov, B. M. Andreichikov, O. M. Kalinkina and I. M. Grechishera, 1971. The chemical composition of the atmosphere of Venus. Planetary Atmospheres, C. Sagan, T. C. Owen and H. J. Smith, Eds., Reidel, Holland, 3-16.

Westenberg, A. A., and N. deHass, 1968: Atom-molecule kinetics using ESR detection IV. Results for $\mathrm{Cl}+\mathrm{H}_{2} \rightleftarrows \mathrm{HCl}+\mathrm{H}$ in both directions. J. Chem. Phys., 48, 4405-4415.

Widing, K. G., J. D. Purcell and G. D. Sandlin, 1970: The UV continuum $1450-2100 \AA$ and the problem of the solar temperature minimum. Solar Phys., 12, 52-62.

Young, A. T., 1973: Are the clouds of Venus sulphuric acid? Icarus, 18, 564-582.

Young, L. D. G., 1972: High resolution spectra of Venus-A review. Icarus, 17, 632-658. 